tained equal as between all birds. The experimental period lasted twelve days. The œstrogen was given intramuscularly in six equal doses on alternate mornings.

The results show that the inclusion of aureomycin in the diet enhanced the response of both serum calcium and serum riboflavin to oestrogen. The effect was about the same as would have been the effect of injecting c. $10 \mathrm{mgm}$. cestradiol benzoate instead of $6 \mathrm{mgm}$., and the relation between serum calcium and serum riboflavin was not apparently disturbed.

It seems possible from this experiment that the addition of antibiotics to a reasonably adequate diet may modify its nutritional effects in such a way that the responsiveness of the pullet to parenteral œestrogen is enhanced. It follows that the responsiveness of the pullet to endogenous oestrogen may likewise be modified by inclusion of antibiotics in its diet. Further experiments would be necessary before attempting to relate this effect of aureomycin to the supply of vitamins $B_{12}$ available for proteinsynthesizing functions $s^{5}$ in the liver.

We are indebted to the National Research Council of Canada for a grant in aid of this work, to Messrs. Schering Corporation for gifts of hormones and to Dr. T. H. Jukes, of Lederle Laboratories, and Dr. N. Nikolaiczuk for a gift of aureomycin hydrochloride.

Faculty of Agriculture,

$$
\begin{aligned}
& \text { R. H. Common } \\
& \text { T. J. KEEFE } \\
& \text { R. BURGESS } \\
& \text { W. A. MAW }
\end{aligned}
$$

McGill University,

Macdonald College,

P.Q., Canada.

$$
\text { Aug. } 15 .
$$

1 Common, R. H., Bolton, W., and Rutledge, W. A., J. Endocrin., 5, 263 (1948).

${ }^{2}$ Fleischmann, W., and Fried, I. A., Endocrin., 86, 406 (1945). 'Hertz, R., Dhyse, F. G., and Tullner, W. W., Endocrin., 44, 283

- Chapman, D. G., Ph.D. thesis, MeGill University (1949). Chapman, D. G., Hanso, A. A., Common, R. H., and Maw, W. A.,
Canad. J. Research, D87, 200 (1949).

\section{Folic Acid as a Growth-Factor for the Rat}

THe recent publication by Aschkenasy-Lelu and Aschkenasy ${ }^{1}$ of their findings on the effects of folic acid on growth and blood composition in the young rat on a synthetic diet with or without adequate protein has prompted us to record a note on some early observations made on folic acid as a growthfactor. As soon as crystalline folic acid became available for biological research in 1946, an experiment was planned to investigate the effect of folic acid on the growth of rats receiving a synthetic diet. Weanling rats of the black-and-white Lister Institute strain were given at 28 days of age a diet consisting of :

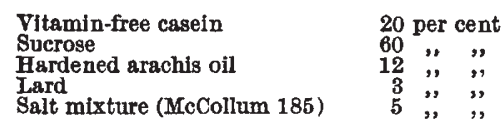

with $0.02 \mathrm{ml}$. cod liver oil daily and $1 \mathrm{ml}$. of a solution of B vitamins containing, per ml. :
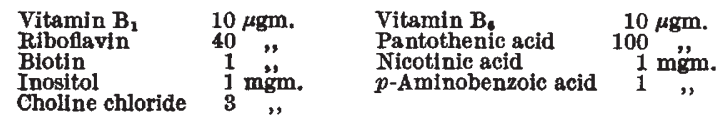

Folic acid was administered separately in daily doses of $0,0 \cdot 5,1 \cdot 0,2 \cdot 0,4 \cdot 0$ or $8 \cdot 0 \mu \mathrm{gm}$. A positive control group of rats was given a crude liver extract in a daily dose equivalent to $6 \mathrm{gm}$. original liver.

In preliminary tests an extracted casein, which was of a dark yellow colour, possibly due to overheating in the drying process, was used and the animals did not grow satisfactorily except in the group receiving crude liver extract. The animals had poor coats and some showed reddish-brown staining of the fur and tail. No macroscopic evidence of liver or kidney damage was found when the animals were killed after seven weeks on the diet. Afterwards, more satisfactory samples of casein were obtained and all animals showed good weight increases during the first four weeks on the diet, with a decline in later weeks. The rats remained in good general condition throughout. The results of a typical experiment are given in the accompanying table.

Weight Ingreases of Rats Rechiving a PURIfTed DIfT with GRADED DOSES OF FOLIC ACID

\begin{tabular}{|c|cc|c|c|}
\hline $\begin{array}{c}\text { Dose of folic } \\
\text { acid }(\mu \mathrm{gm} .)\end{array}$ & $\begin{array}{c}\text { Number and } \\
\text { sex of rats } \\
\text { o }\end{array}$ & $\begin{array}{c}\text { Average weekly } \\
\text { weight increases } \\
\text { (gm. in } \\
\text { 4-week period) }\end{array}$ & $\begin{array}{c}\text { Average weekly } \\
\text { weight increases } \\
\text { (gm. in } \\
\text { 7-week period) }\end{array}$ \\
\hline 0 & 4 & 4 & $15 \cdot 60$ & $12 \cdot 46$ \\
$0 \cdot 5$ & 4 & 4 & $15 \cdot 75$ & $11 \cdot 94$ \\
$1 \cdot 0$ & 3 & 5 & $15 \cdot 38$ & $12 \cdot 55$ \\
$2 \cdot 0$ & 2 & 6 & 16.03 & $12 \cdot 38$ \\
$4 \cdot 0$ & 2 & 6 & 15.47 & 11.95 \\
$8 \cdot 0$ & 4 & 4 & $17 \cdot 69$ & $13 \cdot 45$ \\
Liver extract & 3 & 5 & $21 \cdot 19$ & $14 \cdot 40$ \\
\hline
\end{tabular}

When the differences between the average growth. rates for the different groups were compared by Fisher's $t$-test, no significant differences were found except in the group having liver extract, which grew better than any of the others. This result was repeated in later tests, and it thus appeared that addition of up to $8 \mathrm{\mu gm}$. folic acid daily to the synthetic diet did not affect the weight increase in young rats. It was apparent from the preliminary tests that the nature of the casein component of the diet was of considerable importance in a highly purified diet.

These results are of interest in view of the relation which Aschkenasy-Lelu and Aschkenasy reported between the protein-level in the diet and the response to a daily dose of $50 \mathrm{kgm}$. folic acid. The numbers of rats in their experiments were small; but it seemed that only very small and irregular increases in average growth occurred when the dose of $50 \mu \mathrm{gm}$. folic acid was given with a diet containing 15 per cent casein. When there was 7 per cent of casein in the diet, administration of folic acid appeared to depress growth. Even with 20 per cent of casein in the diet for the present tests the growth response was poor if the casein was not of good quality. It would seem that folic acid is not an essential growth-factor for rats, and that other more important growth-factors present in liver extracts are required to supplement a purified diet. Further details of the study of growth factors are in the course of publication.

Alice M. Copping*

VANDA R. G. PoND

Lister Institute,

London, S.W.1.

* Now at King's College of Household and Social Sclence, Campden Hill Road, London, W.8.

t Aschkenasy-Lelu, P., and Aschkenasy, A., Arch. Internat. Physiol., 56, 152 and 158 (1948). 